\title{
Ru(II)-Thymine Complex Causes Cell Growth Inhibition and Induction of Caspase-Mediated Apoptosis in Human Promyelocytic Leukemia HL-60 Cells
}

\author{
Maiara de Souza Oliveira ${ }^{1}$, Ádila Angélica Dantas de Santana ${ }^{1}$, Rodrigo S. Correa ${ }^{2}$, \\ Milena Botelho Pereira Soares ${ }^{1,3}$, Alzir Azevedo Batista ${ }^{4}$ and Daniel Pereira Bezerra ${ }^{1, *}$ \\ 1 Gonçalo Moniz Institute, Oswaldo Cruz Foundation (IGM-FIOCRUZ/BA), Rua Waldemar Falcão, 121, \\ Candeal, Salvador 40296-710, Bahia, Brazil; msoliveira87@hotmail.com (M.d.S.O.); \\ dantas.adila@gmail.com (Á.A.D.d.S.); milenabpsoares@gmail.com (M.B.P.S.) \\ 2 Department of Chemistry, Federal University of Ouro Preto, Ouro Preto 35400-000, Minas Gerais, Brazil; \\ rodrigoquimic@gmail.com \\ 3 Center of Biotechnology and Cell Therapy, Hospital São Rafael, Salvador 41253-190, Bahia, Brazil \\ 4 Department of Chemistry, Federal University of São Carlos, São Carlos 13561-901, São Paulo, Brazil; \\ daab@ufscar.br \\ * Correspondence: danielpbezerra@gmail.com; Tel./Fax: +55-71-3176-2272
}

Received: 24 March 2018; Accepted: 2 May 2018; Published: 30 May 2018

\begin{abstract}
Ruthenium-based compounds represent a class of potential antineoplastic drugs. Recently, we designed, synthesized, and identified the $\mathrm{Ru}(\mathrm{II})$-thymine complex $\left[\mathrm{Ru}\left(\mathrm{PPh}_{3}\right)_{2}\right.$ (Thy)(bipy) $\mathrm{PF}_{6}$ (where $\mathrm{PPh}=$ triphenylphosphine, Thy = thymine and bipy $=2,2^{\prime}$-bipyridine) as a potent cytotoxic agent with the ability to bind to DNA and human and bovine serum albumins. In this study, the underlying cytotoxic mechanism of the $\left[\mathrm{Ru}\left(\mathrm{PPh}_{3}\right)_{2}(\mathrm{Thy})(\mathrm{bipy})\right] \mathrm{PF}_{6}$ complex was assessed. This complex displayed potent cytotoxicity in different cancer cell lines; the morphology that is associated with apoptotic cell death, increased internucleosomal DNA fragmentation without cell membrane permeability, loss of the mitochondrial transmembrane potential, increased phosphatidylserine externalization, and caspase-3 activation were observed in human promyelocytic leukemia HL-60 cells that were treated with the complex. Moreover, pretreatment of HL-60 cells with Z-VAD(OMe)-FMK, a pan-caspase inhibitor, partially reduced the apoptosis that was induced by the complex, indicating that the apoptotic cell death occurred through a caspase-mediated pathway. In conclusion, the $\left[\mathrm{Ru}\left(\mathrm{PPh}_{3}\right)_{2}\right.$ (Thy)(bipy) $] \mathrm{PF}_{6}$ complex displays potent cytotoxicity to different cancer cells and induces caspase-mediated apoptosis in HL-60 cells.
\end{abstract}

Keywords: ruthenium; thymine; cytotoxicity; apoptosis; HL-60

\section{Introduction}

Cancer is a great public health problem in both developed and developing countries. In 2012, the estimate was approximately 14.1 million new cancer cases and 8.2 million deaths worldwide; among cancer, leukemia has one of the highest incidences worldwide, with approximately 352,000 new cases being diagnosed and approximately 265,500 deaths [1]. Chemotherapy remains an important therapy modality; however, due to side effects and drug resistance, new anticancer compounds are needed.

Ruthenium-based compounds form a class of potential antineoplastic drugs. Therefore, many ruthenium complexes have been designed and synthesized with several ligands, resulting in 
metallodrugs with action in cancer cells of different histological types. Interestingly, this feature is strictly dependent on the nature of the ligands, and the complexes can act via diverse mechanisms, including induction of reactive oxygen species (ROS), binding of DNA, and cell death via apoptosis pathways [2-10]. In particular, NAMI-A ([ImH] [trans- $\left.\mathrm{RuCl}_{4}(\mathrm{DMSO})(\mathrm{Im})\right]$, where $\mathrm{Im}=$ imidazole and DMSO = dimethylsulfoxide $)$ and $\mathrm{KP} 1019\left([\mathrm{IndH}]\left[\right.\right.$ trans- $\left.-\mathrm{RuCl}_{4}(\mathrm{Ind})_{2}\right]$, where Ind $=$ indazole $)$ are currently in phase I/II clinical trials, with promising results [11,12].

In our previous study, we designed, synthesized, and identified the $\mathrm{Ru}(\mathrm{II})$-thymine complex $\left[\mathrm{Ru}\left(\mathrm{PPh}_{3}\right)_{2}\right.$ (Thy)(bipy)]PF 6 (where $\mathrm{PPh}=$ triphenylphosphine, Thy $=$ thymine and bipy $=2,2^{\prime}$-bipyridine) as a potent cytotoxic agent with the ability to bind DNA and human and bovine serum albumins [13]; however, the mechanisms of action of this complex in cancer cells have not been clearly demonstrated. In this study, the mechanism that is underlying the cytotoxicity of the $\left[\mathrm{Ru}\left(\mathrm{PPh}_{3}\right)_{2}(\mathrm{Thy})(\right.$ bipy $\left.)\right] \mathrm{PF}_{6}$ complex (Figure 1) was assessed in human promyelocytic leukemia HL-60 cells.

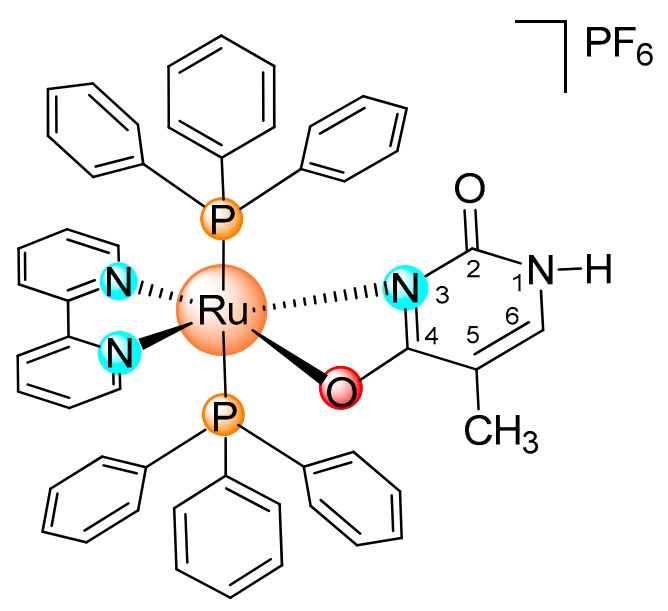

Figure 1. Chemical structure of the $\left[\mathrm{Ru}\left(\mathrm{PPh}_{3}\right)_{2}\right.$ (Thy)(bipy) $] \mathrm{PF}_{6}$ complex.

\section{Results and Discussion}

\subsection{The $\left[R u\left(P P h_{3}\right)_{2}\right.$ (Thy)(bipy)]PF ${ }_{6}$ Complex Exhibits Potent Cytotoxicity in Different Cancer Cells}

The cytotoxicity of the $\left[\mathrm{Ru}\left(\mathrm{PPh}_{3}\right)_{2}\right.$ (Thy)(bipy) $] \mathrm{PF}_{6}$ complex in eight cancer cell lines, HL-60 (human promyelocytic leukemia), K-562 (human chronic myelogenous leukemia), HCT116 (human colon carcinoma), MCF7 (human breast carcinoma), HepG2 (human hepatocellular carcinoma), HSC-3 (human oral squamous cell carcinoma), SCC-9 (human oral squamous cell carcinoma), B16-F10 (mouse melanoma), two noncancerous cells, MRC-5 (human lung fibroblast), and PBMC (human peripheral blood mononuclear cell), was evaluated using the alamar blue (AB) assay after $72 \mathrm{~h}$ of incubation. This small panel of cancer cell lines is representative of colon, breast, liver, tongue, gastric, skin, and hematological cancers. Table 1 shows the $\mathrm{IC}_{50}$ (half maximal inhibitory concentration) values. The complex presented $\mathrm{IC}_{50}$ values ranging from 1.1 to $11.1 \mu \mathrm{M}$ for the HSC-3 and MCF7 cancer cells, respectively. The $\mathrm{IC}_{50}$ values for noncancerous cells were 11.5 and $1.7 \mu \mathrm{M}$ for the MRC- 5 cells and PBMCs, respectively. Doxorubicin presented $\mathrm{IC}_{50}$ values that were ranging from 0.1 to $1.1 \mu \mathrm{M}$ for the HCT116 and MCF7 cancer cells, respectively, and 1.5 and $5.1 \mu \mathrm{M}$ for the noncancerous cells MRC-5 and PBMC, respectively. Oxaliplatin presented $\mathrm{IC}_{50}$ values ranging from 0.6 to $5.7 \mu \mathrm{M}$ for the HL-60 and MCF7 cancer cells, respectively, and 1.3 and $9.4 \mu \mathrm{M}$ for the noncancerous cells MRC-5 and PBMC. Table 2 displays the selectivity index (SI) that was calculated, showing that the complex has an equal or higher SI than the positive controls doxorubicin and oxaliplatin, for many types of cancer cells. 
Table 1. Cytotoxicity of the $\left[\mathrm{Ru}\left(\mathrm{PPh}_{3}\right)_{2}\right.$ (Thy)(bipy) $] \mathrm{PF}_{6}$ complex (CRT).

\begin{tabular}{ccccc}
\hline \multirow{2}{*}{ Cells } & Histological Type & \multicolumn{3}{c}{ IC $_{50}$ in $\mu$ M } \\
\cline { 3 - 5 } & Cancer cells & DOX & OXA & CRT \\
\hline \multirow{2}{*}{ HL-60 } & Human promyelocytic leukemia & 0.3 & 0.6 & 1.4 \\
& & $0.3-0.4$ & $0.1-0.8$ & $0.7-2.8$ \\
K562 & Human chronic myelogenous leukemia & 0.3 & 1.0 & 1.3 \\
& & $0.2-0.5$ & $0.1-1.3$ & $0.9-2.0$ \\
HCT116 & Human colon carcinoma & 0.1 & 4.1 & 1.6 \\
& & $0.1-0.2$ & $2.7-6.4$ & $1.2-2.2$ \\
MCF7 & Human breast carcinoma & 1.1 & 5.7 & 11.1 \\
& & $0.3-3.5$ & $3.3-9.4$ & $7.9-15.5$ \\
HepG2 & Human hepatocellular carcinoma & 0.1 & 2.2 & 2.8 \\
& & $0.1-0.2$ & $1.3-3.8$ & $2.3-3.3$ \\
HSC3 & Human oral squamous cell carcinoma & 0.3 & 3.1 & 1.1 \\
& & $0.2-0.4$ & $1.6-5.3$ & $0.8-1.5$ \\
SCC9 & Human oral squamous cell carcinoma & 0.5 & N.d. & 2.4 \\
& & $0.4-0.7$ & & $1.7-3.5$ \\
B16-F10 & Mouse melanoma & 0.1 & 2.2 & 1.4 \\
& & $0.1-0.2$ & $1.2-4.1$ & $1.2-1.8$ \\
\hline \multirow{2}{*}{ MRC5 } & Non-cancer cells & 1.5 & 1.3 & 11.5 \\
& Human lung fibroblast & $1.2-2.0$ & $1.0-2.2$ & $10.3-12.9$ \\
PBMC & Human peripheral blood mononuclear cells & 5.1 & 9.4 & 1.7 \\
& & $3.2-8.2$ & $6.5-11.4$ & $1.4-2.0$ \\
\hline
\end{tabular}

Data are presented as $\mathrm{IC}_{50}$ values in $\mu \mathrm{M}$ and their respective $95 \%$ confidence interval, obtained by nonlinear regression from at the least three independent experiments, measured by the alamar blue (AB) assay after $72 \mathrm{~h}$ of incubation. Doxorubicin (DOX) and oxaliplatin (OXA) were used as the positive controls. N.d. Not determined.

Table 2. Selectivity index of the $\left[\mathrm{Ru}\left(\mathrm{PPh}_{3}\right)_{2}\right.$ (Thy)(bipy) $] \mathrm{PF}_{6}$ complex (CRT).

\begin{tabular}{|c|c|c|c|c|c|c|}
\hline \multirow{3}{*}{ Cancer Cells } & \multicolumn{6}{|c|}{ Non-Cancer Cells } \\
\hline & \multicolumn{3}{|c|}{ MRC5 } & \multicolumn{3}{|c|}{ PBMC } \\
\hline & DOX & OXA & CRT & DOX & OXA & CRT \\
\hline HL-60 & 5 & 2.2 & 8.2 & 17 & 15.7 & 1.2 \\
\hline K-562 & 5 & 1.3 & 8.8 & 17 & 9.4 & 1.3 \\
\hline HCT116 & 15 & 0.3 & 7.2 & 51 & 2.3 & 1.1 \\
\hline MCF7 & 1.4 & 0.2 & 1 & 4.6 & 1.7 & 0.2 \\
\hline HepG2 & 15 & 0.6 & 4.1 & 51 & 4.3 & 0.6 \\
\hline HSC-3 & 5 & 0.4 & 10.5 & 17 & 3.0 & 1.6 \\
\hline SCC-9 & 3 & N.d. & 4.8 & 10.2 & N.d. & 0.7 \\
\hline B16-F10 & 15 & 0.6 & 8.2 & 51 & 4.3 & 1.2 \\
\hline
\end{tabular}

Data are presented the selectivity index (SI) calculated using the following formula: $\mathrm{SI}=\mathrm{IC}_{50}$ [noncancerous cells]/IC 50 [cancer cells]. Cancer cells: HL-60 (human promyelocytic leukemia); K-562 (human chronic myelogenous leukemia); HCT116 (human colon carcinoma); MCF7 (human breast carcinoma); HepG2 (human hepatocellular carcinoma); HSC-3 (human oral squamous cell carcinoma); SCC-9 (human oral squamous cell carcinoma); and, B16-F10 (mouse melanoma). Noncancerous cells: MRC-5 (human lung fibroblast) and PBMC (human peripheral blood mononuclear cell). Doxorubicin (DOX) and oxaliplatin (OXA) were used as the positive controls. N.d. Not determined.

In a new set of experiments, the human promyelocytic leukemia HL-60 cell line was used as a cellular model, since this cell line was among the most sensitive to the $\left[\mathrm{Ru}\left(\mathrm{PPh}_{3}\right)_{2}(\mathrm{Thy})(\right.$ bipy $\left.)\right] \mathrm{PF}_{6}$ complex. Moreover, the HL-60 cell line is a cellular model often used to study the mechanism of the antileukemia action of new compounds [14-18]. Cell viability after treatment with the complex was confirmed by a trypan blue exclusion (TBE) assay in HL-60 cells after 24 and $48 \mathrm{~h}$ of incubation (Figure 2). At concentrations of 1,2, and $4 \mu \mathrm{M}$, the complex reduced the number of viable cells by, respectively, $32.5 \%, 49.1 \%$, and $59.1 \%$ after $24 \mathrm{~h}$ and by $62.6 \%, 66.6 \%$ and $73.4 \%$ after $48 \mathrm{~h}$. No significant increase in the number of nonviable cells was observed. Doxorubicin $(2 \mu \mathrm{M})$ reduced the number of 
viable cells by $58.0 \%$ after $24 \mathrm{~h}$ and by $88.1 \%$ after $48 \mathrm{~h}$, while oxaliplatin $(2.5 \mu \mathrm{M})$ reduced the number of viable cells by $37.0 \%$ after $24 \mathrm{~h}$ and by $70.0 \%$ after $48 \mathrm{~h}$.
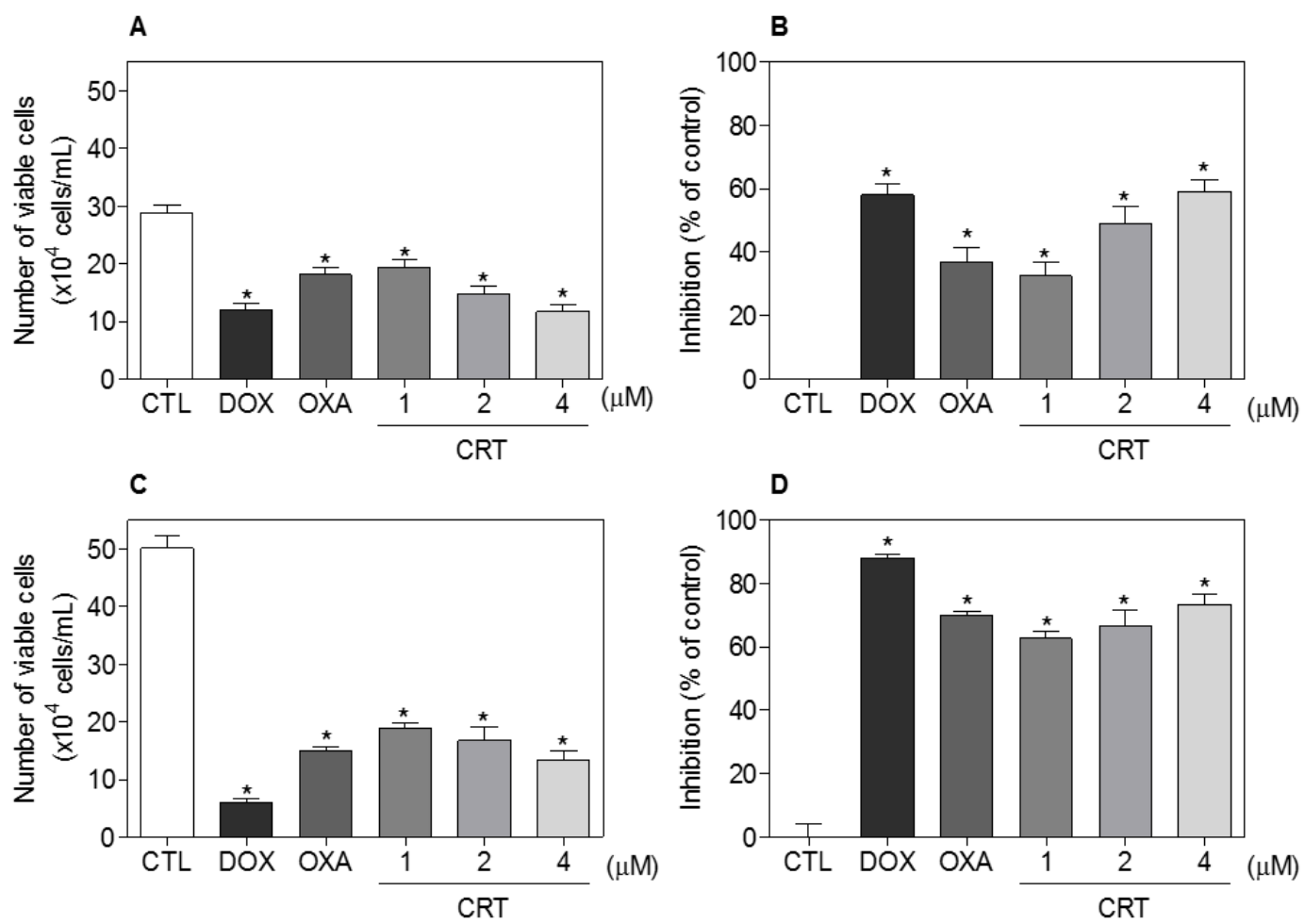

Figure 2. Effect of the $\left[\mathrm{Ru}\left(\mathrm{PPh}_{3}\right)_{2}\right.$ (Thy)(bipy) $] \mathrm{PF}_{6}$ complex (CRT) on the cell viability of HL-60 cells determined by the trypan blue exclusion (TBE) assay after 24 (A,B) and 48 (C,D) h of incubation. The negative control (CTL) received $0.1 \%$ DMSO, and the positive controls received doxorubicin (DOX, $2 \mu \mathrm{M}$ ) or oxaliplatin (OXA, $2.5 \mu \mathrm{M}$ ). Data are presented as the mean \pm S.E.M. of three independent experiments performed in duplicate. ${ }^{*} p<0.05$ as compared with the negative control by ANOVA, followed by the Student Newman-Keuls test.

Other ruthenium complexes have been previously reported as potent cytotoxic agents, including cyclometalated ruthenium $\beta$-carboline complexes, which were cytotoxic to lung, liver, breast, and cervical cancers [8]; piplartine-containing ruthenium complexes, which were cytotoxic to colon, tongue, liver, breast, skin, and hematological cancers [5]; a ruthenium complex with xanthoxylin, which was cytotoxic to colon, breast, liver, tongue, gastric, skin, and hematological cancers [9]; ruthenium imidazole complexes, which were cytotoxic to lung, liver, breast, and cervical cancers [19]; and, a ruthenium-based 5-fluorouracil complex, which had enhanced cytotoxicity to breast, colon, liver, tongue, skin, and hematological cancers [10]. The $\mathrm{IC}_{50}$ values of these compounds are below $10 \mu \mathrm{M}$ for most of the tested cancer cell lines. Herein, the $\mathrm{Ru}(\mathrm{II})$-thymine complex presented $\mathrm{IC}_{50}$ values below $3 \mu \mathrm{M}$ for most of the tested cancer cell lines. These data corroborate our previous study, where this complex was tested against a small panel of cancer cells (B16-F10, HepG2, K562, and HL-60), with which it had $\mathrm{IC}_{50}$ values below $2 \mu \mathrm{M}$ [13].

\subsection{The $\left[R u\left(P P h_{3}\right)_{2}\right.$ (Thy)(bipy)]PF ${ }_{6}$ Complex Triggers Caspase-Mediated Apoptosis in HL-60 Cells}

The biochemical and morphological correlates of apoptotic cell death include phosphatidylserine exposure, loss of the mitochondrial transmembrane potential (intrinsic apoptosis), activation of caspases, DNA fragmentation (karyorrhexis), chromatin condensation (pyknosis), cytoplasmic shrinkage, dynamic membrane blebbing, and the formation of apoptotic bodies [20,21]. HL-60 cells that were treated with the $\left[\mathrm{Ru}\left(\mathrm{PPh}_{3}\right)_{2}\right.$ (Thy)(bipy) $] \mathrm{PF}_{6}$ complex showed cell morphology changes that were associated 
with apoptosis, including a reduction in the cell volume, chromatin condensation, and fragmentation of the nuclei, as observed in May-Grunwald-Giemsa-stained cells (Figure 3A). Furthermore, the complex caused cell shrinkage, as indicated by the decrease in forward light scatter (FSC) (Figures 3B and 4A), as well as nuclear condensation, as indicated by an increase in side scatter (SCC) (Figures 3B and 4B), which were both assessed by flow cytometry. Doxorubicin and oxaliplatin also caused cell death by apoptosis.

The internucleosomal DNA fragmentation and cell cycle distribution were assessed in HL-60 cells after 24 and $48 \mathrm{~h}$ of incubation with the $\left[\mathrm{Ru}\left(\mathrm{PPh}_{3}\right)_{2}(\mathrm{Thy})(\right.$ bipy $\left.)\right] \mathrm{PF}_{6}$ complex in a DNA content-based assay using the dye propidium iodide (PI) and flow cytometry (Table 3). All DNA with a subdiploid size (sub- $\mathrm{G}_{0} / \mathrm{G}_{1}$ ) were considered to be fragmented. At concentrations of 1,2 , and $4 \mu \mathrm{M}$, the complex led to, respectively, $19.4 \%, 30.1 \%$, and $36.2 \%$ DNA fragmentation after $24 \mathrm{~h}$ of incubation and to $12.5 \%, 26.7 \%$, and $58.2 \%$ DNA fragmentation after $48 \mathrm{~h}$ of incubation. Doxorubicin also induced DNA fragmentation. Oxaliplatin caused cell cycle arrest at the $\mathrm{G}_{2} / \mathrm{M}$ phase and induced DNA fragmentation.

A

CTL

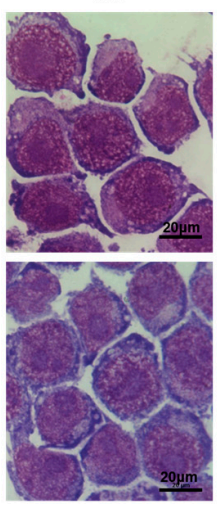

DOX

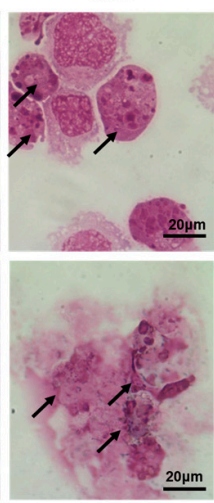

OXA
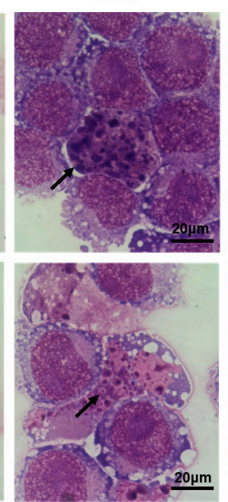

$\mathrm{CRT}-1 \mu \mathrm{M}$

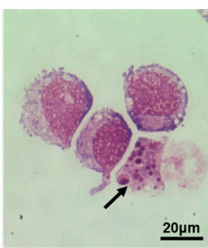

$\underline{20 \mu m}$

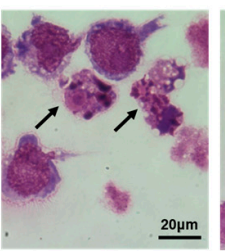

CRT $-2 \mu \mathrm{M}$
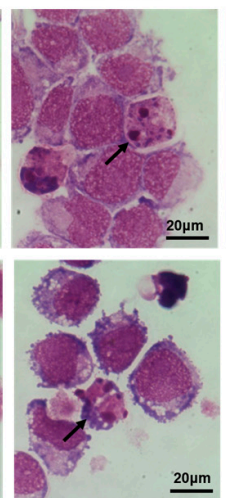

CRT $-4 \mu \mathrm{M}$

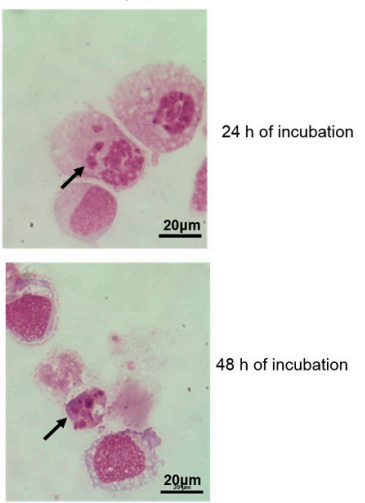

CTL

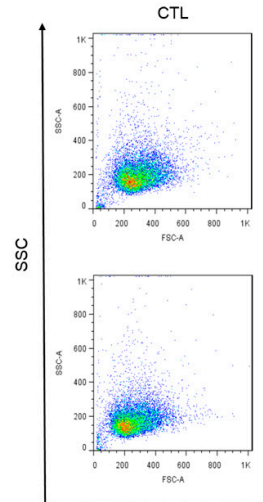

DOX
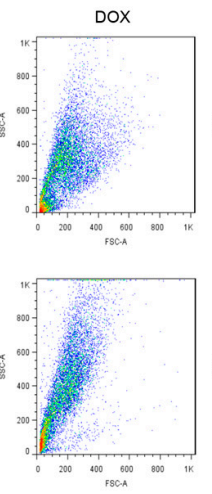

OXA
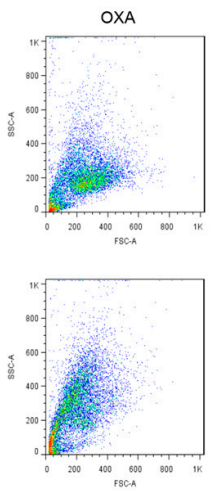
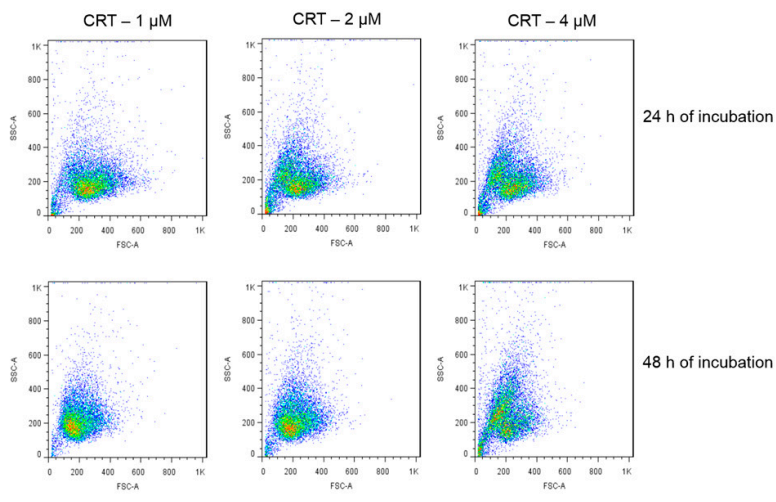

Figure 3. Effect of the $\left[\mathrm{Ru}\left(\mathrm{PPh}_{3}\right)_{2}\right.$ (Thy)(bipy)]PF 6 complex (CRT) on the morphology of HL-60 cells after 24 and $48 \mathrm{~h}$ of incubation. (A) Cells stained with May-Grunwald-Giemsa and were examined by light microscopy $($ bar $=20 \mu \mathrm{m})$. Arrows indicate cells with reduced cell volume, chromatin condensation or fragmented DNA; (B) Light scattering features determined by flow cytometry. The negative control $(\mathrm{CTL})$ received $0.1 \% \mathrm{DMSO}$, and the positive controls received doxorubicin (DOX, $2 \mu \mathrm{M})$ or oxaliplatin (OXA, $2.5 \mu \mathrm{M})$. The dot plots are expressed in arbitrary units. FSC: forward scatter; SCC: side scatter. 
A

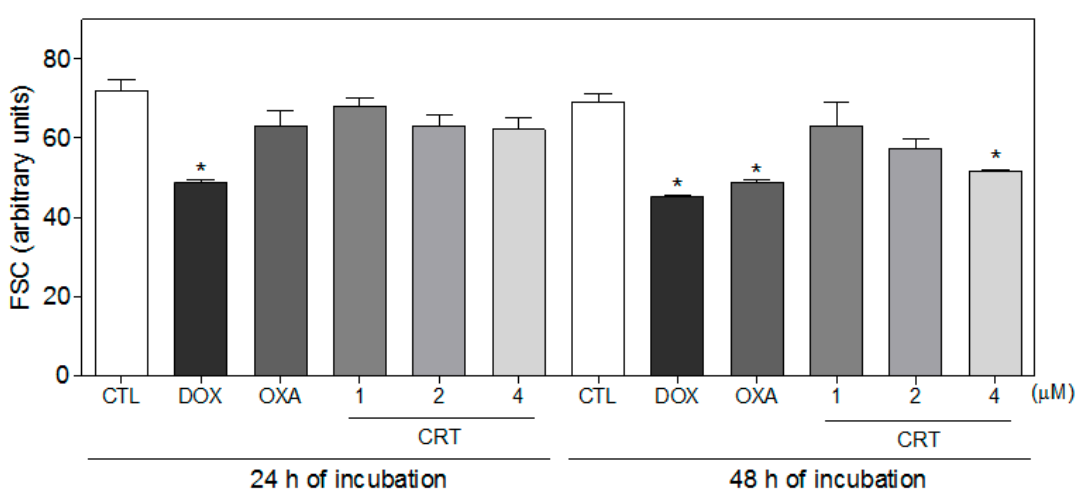

B

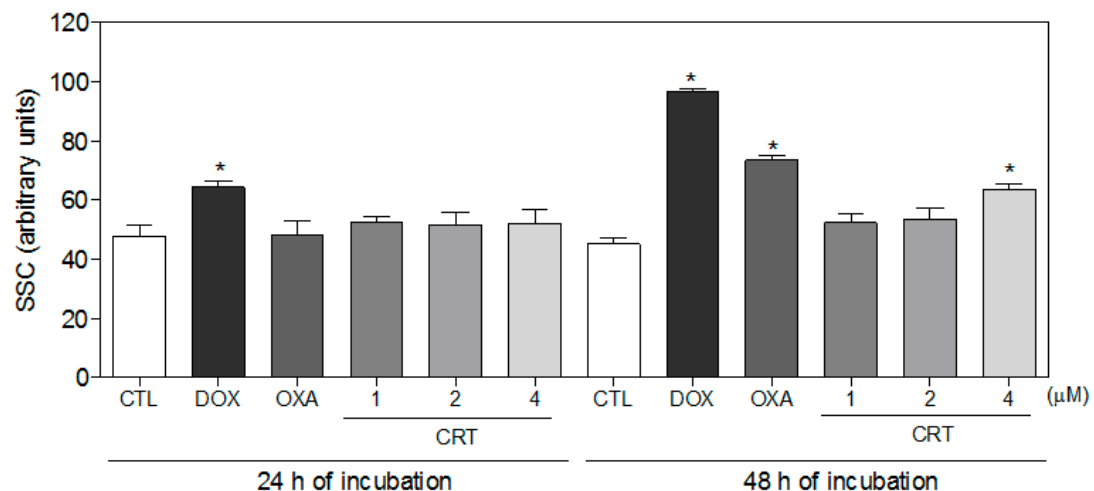

Figure 4. Effect of the $\left[\mathrm{Ru}\left(\mathrm{PPh}_{3}\right)_{2}\right.$ (Thy)(bipy) $] \mathrm{PF}_{6}$ complex (CRT) on the morphology of HL-60 cells after 24 and $48 \mathrm{~h}$ of incubation. (A) Quantification of forward light scatter (FSC) determined by flow cytometry; and (B) Quantification of side scatter (SCC), as determined by flow cytometry. The negative control (CTL) received $0.1 \% \mathrm{DMSO}$, and the positive controls received doxorubicin (DOX, $2 \mu \mathrm{M})$ or oxaliplatin (OXA, $2.5 \mu \mathrm{M}$ ). Data are presented as the mean \pm S.E.M. of at the least three independent experiments. ${ }^{*} p<0.05$ as compared with the negative control by ANOVA, followed by the Student Newman-Keuls test.

Table 3. Effect of the $\left[\mathrm{Ru}\left(\mathrm{PPh}_{3}\right)_{2}\right.$ (Thy)(bipy) $] \mathrm{PF}_{6}$ complex (CRT) on the cell cycle distribution of HL-60 cells.

\begin{tabular}{|c|c|c|c|c|c|}
\hline \multirow{2}{*}{ Treatment } & \multirow{2}{*}{ Concentration $(\mu \mathrm{M})$} & \multicolumn{4}{|c|}{ DNA Content (\%) } \\
\hline & & Sub-G ${ }_{0} / \mathrm{G}_{1}$ & $\mathrm{G}_{0} / \mathrm{G}_{1}$ & $S$ & $\mathrm{G}_{2} / \mathrm{M}$ \\
\hline \multicolumn{6}{|c|}{$24 \mathrm{~h}$ of incubation } \\
\hline CTL & - & $11.5 \pm 1.4$ & $50.7 \pm 5.5$ & $15.0 \pm 2.5$ & $16.3 \pm 0.7$ \\
\hline DOX & 2 & $58.6 \pm 2.5^{*}$ & $19.9 \pm 2.5^{*}$ & $6.6 \pm 1.6^{*}$ & $8.9 \pm 1.5^{*}$ \\
\hline OXA & 2.5 & $21.9 \pm 3.3^{*}$ & $31.4 \pm 3.0^{*}$ & $11.6 \pm 2.3$ & $26.0 \pm 3.6^{*}$ \\
\hline \multirow[t]{3}{*}{ CRT } & 1 & $19.4 \pm 3.9^{*}$ & $30.5 \pm 4.8^{*}$ & $11.5 \pm 1.7$ & $18.5 \pm 0.7$ \\
\hline & 2 & $30.1 \pm 7.9 *$ & $38.7 \pm 2.2 *$ & $7.8 \pm 1.5^{*}$ & $17.9 \pm 4.4$ \\
\hline & 4 & $36.2 \pm 9.5^{*}$ & $36.3 \pm 3.1^{*}$ & $10.4 \pm 2.4$ & $13.2 \pm 4.1$ \\
\hline \multicolumn{6}{|c|}{$48 \mathrm{~h}$ of incubation } \\
\hline CTL & - & $7.5 \pm 1.0$ & $58.5 \pm 3.1$ & $14.1 \pm 1.3$ & $17.0 \pm 1.6$ \\
\hline DOX & 2 & $65.4 \pm 2.8^{*}$ & $21.9 \pm 3.0 *$ & $6.5 \pm 0.6^{*}$ & $3.8 \pm 0.9 *$ \\
\hline OXA & 2.5 & $18.4 \pm 4.4^{*}$ & $42.9 \pm 2.8^{*}$ & $14.2 \pm 1.2$ & $19.1 \pm 3.3$ \\
\hline \multirow[t]{3}{*}{ CRT } & 1 & $12.5 \pm 3.5^{*}$ & $41.2 \pm 9.6^{*}$ & $11.2 \pm 2.4$ & $10.8 \pm 2.5$ \\
\hline & 2 & $26.7 \pm 7.0^{*}$ & $42.6 \pm 4.9 *$ & $10.5 \pm 0.8 *$ & $14.4 \pm 2.5$ \\
\hline & 4 & $58.2 \pm 8.8^{*}$ & $28.4 \pm 5.9^{*}$ & $4.4 \pm 1.2^{*}$ & $5.5 \pm 2.6^{*}$ \\
\hline
\end{tabular}

Data are presented as the mean \pm S.E.M. of three independent experiments performed in duplicate. The negative control (CTL) received $0.1 \%$ DMSO, and the positive controls received doxorubicin (DOX, $2 \mu \mathrm{M}$ ) or oxaliplatin (OXA, $2.5 \mu \mathrm{M}) .{ }^{*} p<0.05$ compared with the negative control by ANOVA, followed by Student Newman-Keuls test. 
Additionally, annexin $\mathrm{V}$, which is a $\mathrm{Ca}^{2+}$-dependent protein with high affinity for phosphatidylserine, was conjugated to a fluorochrome to detect phosphatidylserine exposure using flow cytometry. Since phosphatidylserine exposure precedes the loss of membrane integrity, annexin V staining was used along with the dye PI to identify early and late apoptotic cells, as well as necrotic cells [22]. Therefore, annexin V-FITC/PI double staining was applied to HL-60 cells that were treated with the $\left[\mathrm{Ru}\left(\mathrm{PPh}_{3}\right)_{2}\right.$ (Thy)(bipy)] $\mathrm{PF}_{6}$ complex after 24 and $48 \mathrm{~h}$ of incubation, and the numbers of viable, early apoptotic, late apoptotic, and necrotic cells were quantified by flow cytometry (Figure 5). The complex induced a significant increase in the percentage of apoptotic cells (early apoptotic cells + late apoptotic cells). No significant increase in the percentage of necrotic cells was observed.

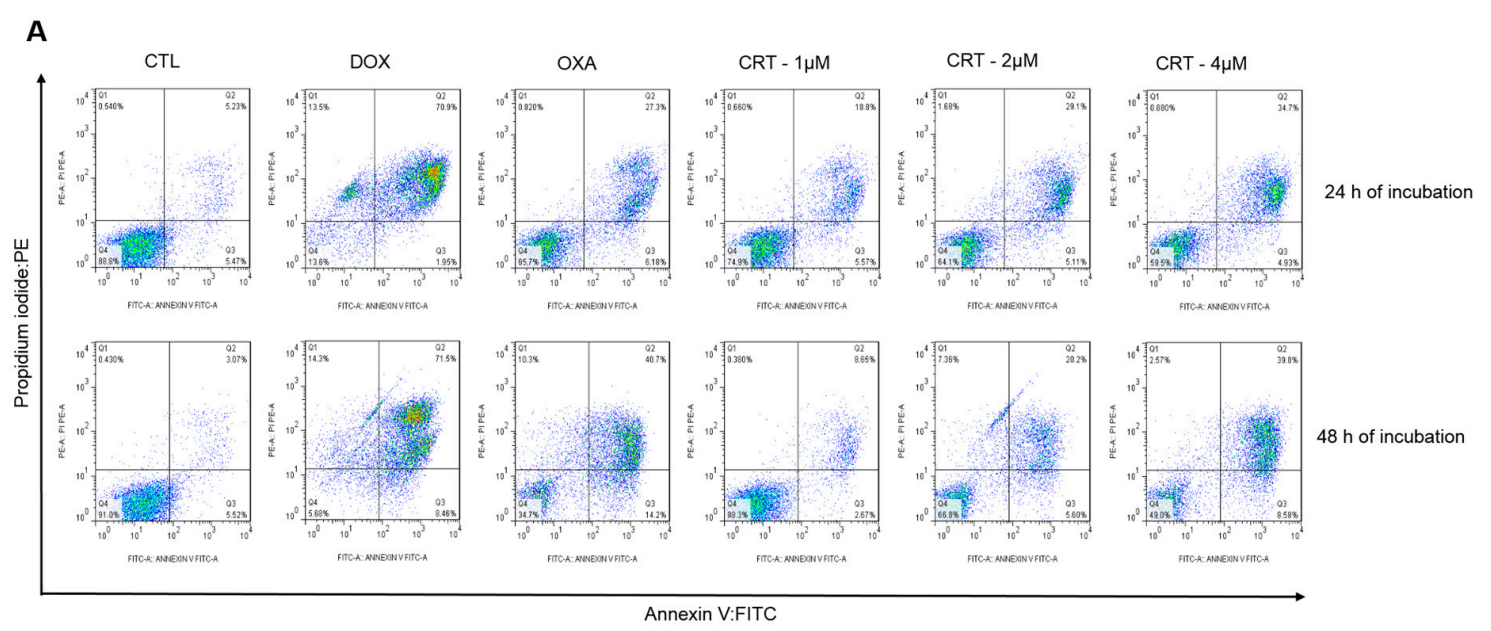

B

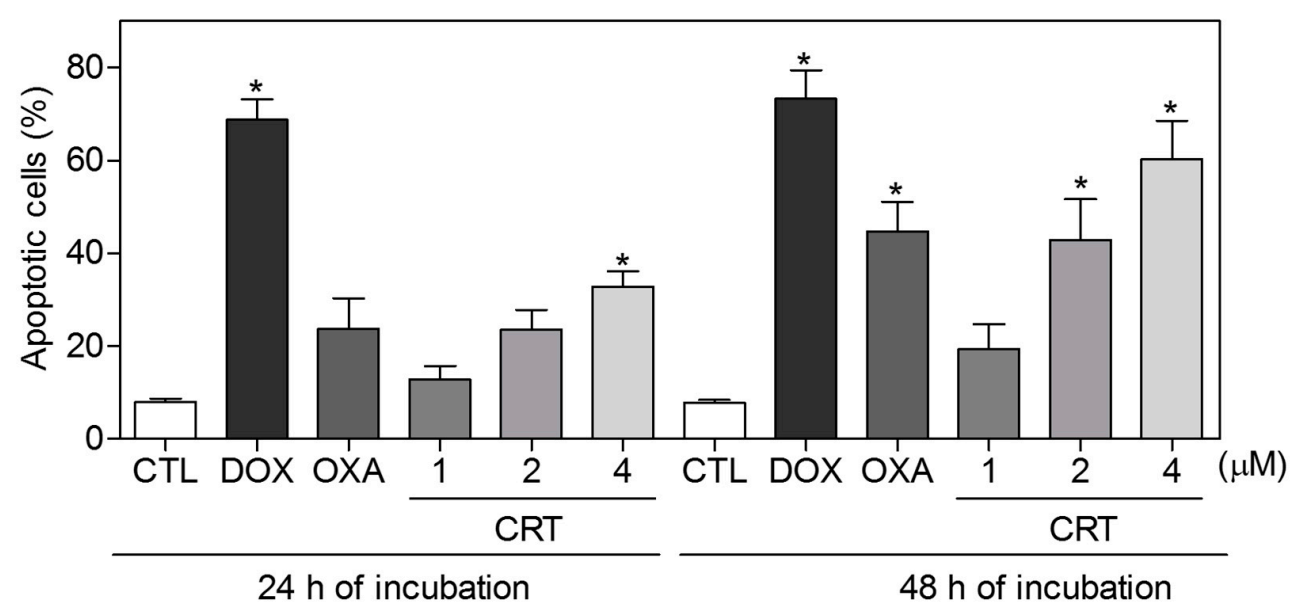

Figure 5. Evaluation of the apoptosis induced by the $\left[\mathrm{Ru}\left(\mathrm{PPh}_{3}\right)_{2}(\mathrm{Thy})(\right.$ bipy $\left.)\right] \mathrm{PF}_{6}$ complex (CRT) in HL-60 cells determined by flow cytometry using annexin V-FITC/PI staining after 24 and $48 \mathrm{~h}$ of incubation. (A) Representative flow cytometry dot plots; (B) Apoptotic cell quantification (annexin V-FITC positive cells). The negative control (CTL) received $0.1 \%$ DMSO, and the positive controls received doxorubicin (DOX, $2 \mu \mathrm{M}$ ) or oxaliplatin (OXA, $2.5 \mu \mathrm{M})$. Data are presented as the mean \pm S.E.M. of at the least three independent experiments. ${ }^{*} p<0.05$ as compared with the negative control by ANOVA, followed by the Student Newman-Keuls test.

Loss of the mitochondrial transmembrane potential is a critical step in intrinsic apoptosis, and activation of caspase-3 (an executioner caspase) favors DNA fragmentation [20,21]. The complex also induced activation of caspase-3 in HL-60 cells (Figure 6A) and it caused the loss of the mitochondrial transmembrane potential (Figure 6B). In addition, cotreatment with a pan-caspase 
inhibitor, Z-VAD(OMe)-FMK, partially prevented the complex-induced increase in apoptotic cells (Figure 7), indicating the induction of caspase-mediated apoptosis in HL-60 cells by the $\left[\mathrm{Ru}\left(\mathrm{PPh}_{3}\right)_{2}(\mathrm{Thy})(\right.$ bipy $\left.)\right] \mathrm{PF}_{6}$ complex. On the other hand, additional mechanisms also appear to be involved in the complex induced-apoptosis, since the pan-caspase inhibitor was not able to fully inhibit the apoptosis that was caused by the complex. Doxorubicin and oxaliplatin also caused an increase in the percentage of apoptotic cells.

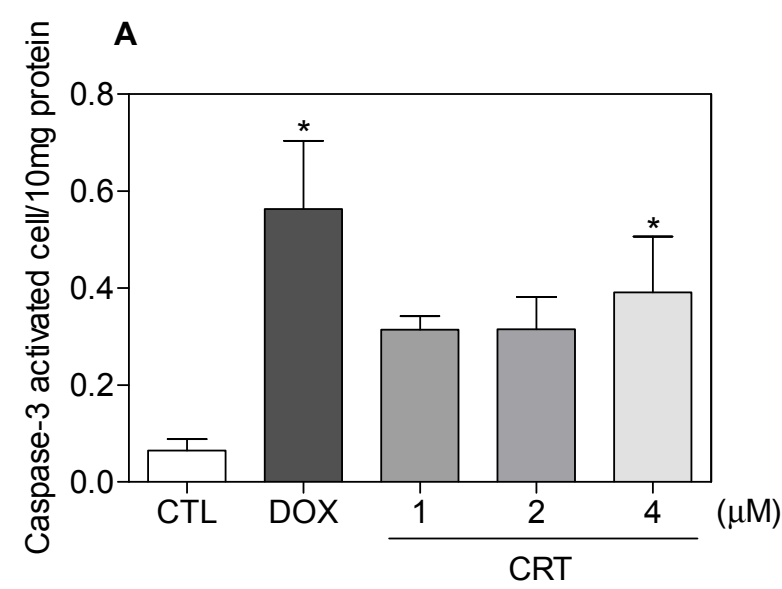

B

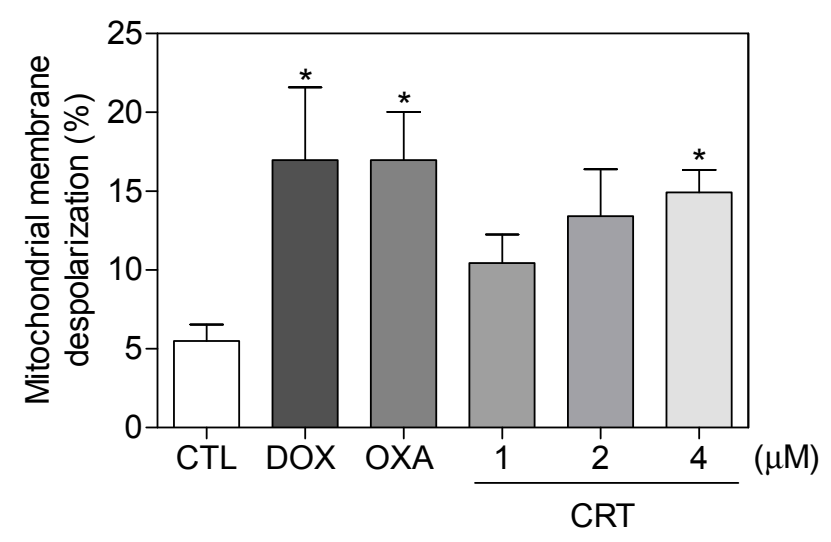

Figure 6. Caspase-3 activity (A), assessed by a colorimetric assay after $48 \mathrm{~h}$ of incubation, and mitochondrial membrane potential (B), evaluated by flow cytometry using rhodamine 123 staining after $24 \mathrm{~h}$ of incubation, of HL-60 cells treatment with the $\left[\mathrm{Ru}\left(\mathrm{PPh}_{3}\right)_{2}\right.$ (Thy)(bipy) $] \mathrm{PF}_{6}$ complex (CRT). The negative control (CTL) received $0.1 \%$ DMSO, and the positive controls received doxorubicin (DOX, $2 \mu \mathrm{M})$ or oxaliplatin (OXA, $2.5 \mu \mathrm{M})$. Data are presented as the mean \pm S.E.M. of at the least three independent experiments. ${ }^{*} p<0.05$ as compared with the negative control by ANOVA, followed by the Student Newman-Keuls test.

As previously mentioned, many ruthenium complexes are known to induce apoptosis. Ruthenium imidazole complexes induce $\mathrm{G}_{0} / \mathrm{G}_{1}$ arrest and apoptosis in A549 and NCI-H460 cells through extrinsic and intrinsic mitochondrial pathways. In addition, these complexes induce cytoprotective autophagy via the ROS-mediated extracellular signal-regulated kinase (ERK) signaling pathway, and the inhibition of autophagy could facilitate cell apoptosis [19]. The ruthenium complex with xanthoxylin induces S-phase arrest and causes ERK1/2-mediated apoptosis in HepG2 cells through a p53-independent pathway [9]. The ruthenium complexes with phenylterpyridine derivatives trigger death receptor-mediated apoptosis in A375 cells [23]. Cyclometalated ruthenium $\beta$-carboline complexes induce apoptosis in HeLa cells, mainly through mitochondrial dysfunction, intracellular ROS accumulation, and ROS-mediated DNA damage [8]. Piplartine-containing ruthenium 
complexes induce caspase-dependent and intrinsic mitochondrial apoptosis in HCT116 cells through a ROS-mediated pathway [5]. Ruthenium polypyridyl complexes induce apoptosis in BEL-7402 cells through a ROS-mediated mitochondrial dysfunction pathway [24]. Moreover, the ruthenium-based 5-fluorouracil complex induces caspase-mediated apoptosis in HCT116 cells [10]. Herein, we observed that the $\mathrm{Ru}(\mathrm{II})$-thymine complex induces caspase-mediated apoptosis in HL-60 cells.

\section{A}

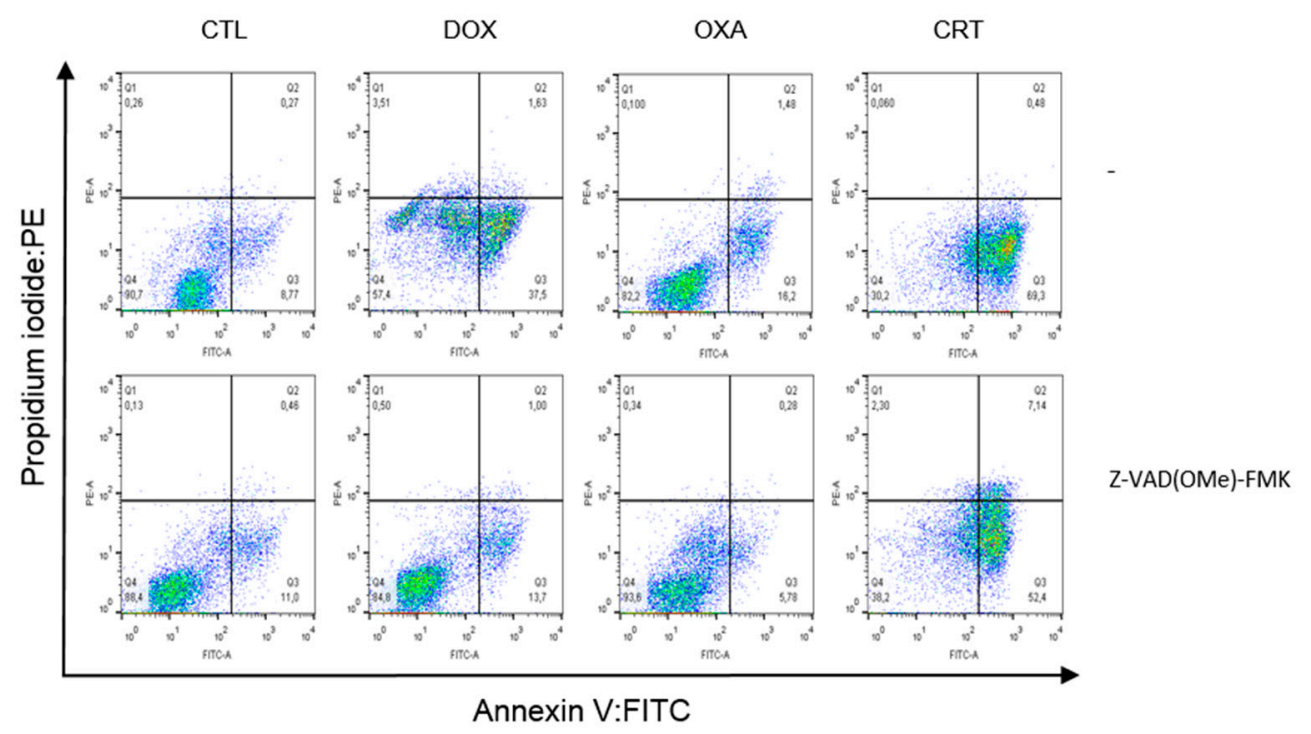

Annexin V:FITC

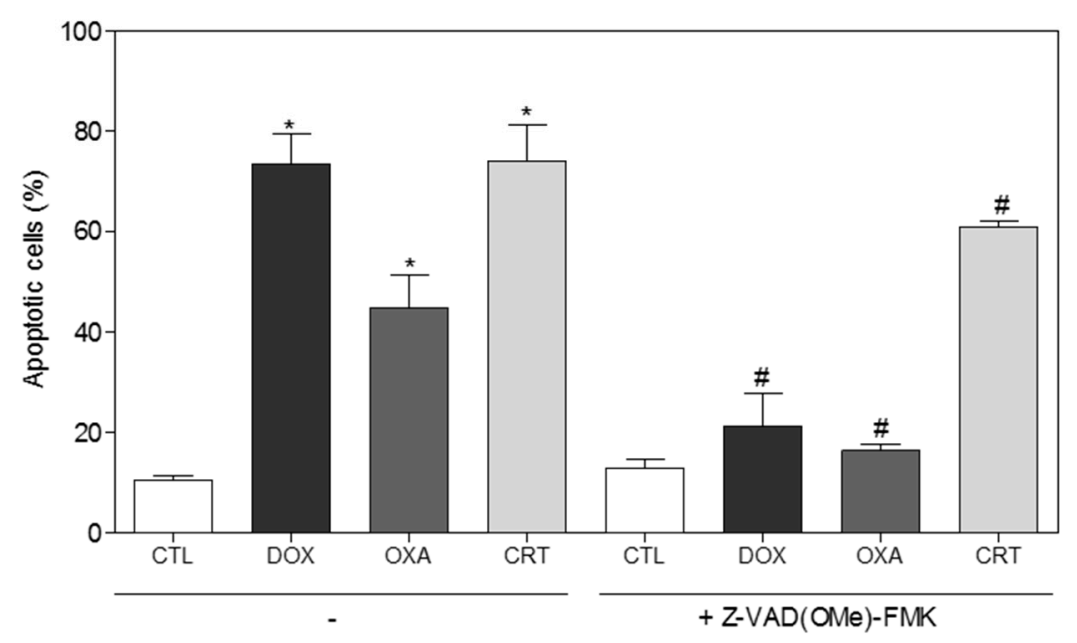

Figure 7. Prevention of the apoptosis induced by the $\left[\mathrm{Ru}\left(\mathrm{PPh}_{3}\right)_{2}(\mathrm{Thy})(\mathrm{bipy})\right] \mathrm{PF}_{6}$ complex $(\mathrm{CRT})$ in HL-60 cells by a pan-caspase inhibitor (Z-VAD(OMe)-FMK), as assessed by flow cytometry using annexin V-FITC/PI staining. (A) Representative flow cytometry dot plots; (B) Apoptotic cell quantification (annexin V-FITC positive cells). The cells were pretreated for $2 \mathrm{~h}$ with $50 \mu \mathrm{M}$ $\mathrm{Z}-\mathrm{VAD}(\mathrm{OMe})-\mathrm{FMK}$ and then incubated with $4 \mu \mathrm{M}$ CRT for $48 \mathrm{~h}$. The negative control (CTL) received $0.1 \%$ DMSO, and the positive controls received doxorubicin (DOX, $2 \mu \mathrm{M}$ ) or oxaliplatin (OXA, $2.5 \mu \mathrm{M}$ ). Data are presented as the mean \pm S.E.M. of at the least three independent experiments. ${ }^{*} p<0.05$ as compared with the negative control by ANOVA, followed by the Student Newman-Keuls test. ${ }^{\#} p<0.05$ as compared with the respective treatment without inhibitor by ANOVA, followed by the Student Newman-Keuls test.

The protein Bcl-2-associated death promoter (BAD) is a pro-apoptotic member of the Bcl-2 family $[20,21]$. The cytotoxicity of the $\left[\mathrm{Ru}\left(\mathrm{PPh}_{3}\right)_{2}(\mathrm{Thy})(\right.$ bipy $\left.)\right] \mathrm{PF}_{6}$ complex was also examined in BAD 
gene knockout immortalized mouse embryonic fibroblasts (BAD KO SV40 MEF) and its parental cell line, wild-type immortalized mouse embryonic fibroblasts (WT SV40 MEF) while using the AB assay after $72 \mathrm{~h}$ of incubation. The complex presented $\mathrm{IC}_{50}$ values of $2.4 \mu \mathrm{M}$ in BAD KO SV40 MEF cells and 2.2 $\mu \mathrm{M}$ in WT SV40 MEF cells, suggesting that the BAD gene is not essential for the cytotoxicity that is induced by the tested complex. Doxorubicin presented $\mathrm{IC}_{50}$ values of 1.3 and $0.8 \mu \mathrm{M}$, and 5-fluorouracil presented IC $_{50}$ values of 11.2 and $5.7 \mu \mathrm{M}$ in BAD KO SV40 MEF and WT SV40 MEF cell, respectively.

The induction of ROS production is also an important mechanism for inducing apoptosis. However, the $\left[\mathrm{Ru}\left(\mathrm{PPh}_{3}\right)_{2}(\mathrm{Thy})(\right.$ bipy $\left.)\right] \mathrm{PF}_{6}$ complex did not induce a significant increase in ROS levels after 1 or $3 \mathrm{~h}$ of incubation at the tested concentrations (data not shown). Moreover, pretreatment with the antioxidant $N$-acetyl-L-cysteine (NAC) did not prevent the increase in apoptotic cells that was caused by the complex (data not shown).

In conclusion, the $\left[\mathrm{Ru}\left(\mathrm{PPh}_{3}\right)_{2}\right.$ (Thy)(bipy) $] \mathrm{PF}_{6}$ complex displays potent cytotoxicity to different cancer cells. In studies of the underlying cytotoxic mechanism, we observed the morphology associated with apoptotic cell death, increased internucleosomal DNA fragmentation without cell membrane permeability changes, a loss of the mitochondrial transmembrane potential, increased phosphatidylserine externalization, and caspase- 3 activation in complex-treated HL-60 cells. The pretreatment of HL-60 cells with Z-VAD(OMe)-FMK, which is a pan-caspase inhibitor, partially reduced the apoptosis that was induced by the complex, indicating that the apoptotic cell death occurred through caspase-mediated pathways.

\section{Materials and Methods}

\subsection{Synthesis of the $\left[R u\left(P P h_{3}\right)_{2}(\right.$ Thy $)($ bipy $\left.)\right] P F_{6}$ Complex}

The $\left[\mathrm{Ru}\left(\mathrm{PPh}_{3}\right)_{2}\right.$ (Thy)(bipy)] $\mathrm{PF}_{6}$ complex was obtained, as previously described by Correa et al. [13]. Briefly, thymine $(23 \mathrm{mg} ; 0.18 \mathrm{mmol})$ was dissolved in a Schlenk flask with $50 \mathrm{~mL}$ of a dichloromethane/methanol mixture $(1: 1 v / v)$ containing triethylamine $(10 \mu \mathrm{L})$ and KPF $6(0.12 \mathrm{mmol}$; $15.0 \mathrm{mg})$. Next, $100 \mathrm{mg}(0.12 \mathrm{mmol})$ of the precursor $\left[\mathrm{RuCl}_{2}\left(\mathrm{PPh}_{3}\right)_{2}(\mathrm{bipy})\right]$ was added. The solution was kept under reflux and in an inert atmosphere, and was stirred for $48 \mathrm{~h}$. The final solution was concentrated to $2 \mathrm{~mL}$, and $10 \mathrm{~mL}$ of water was added to precipitate an orange powder. The solids were filtered off, washed with separately with warm water and diethyl ether, and then dried under vacuum. All of the manipulations were performed under argon. All of the reagents were purchased from Sigma-Aldrich (Sigma-Aldrich Co., Saint Louis, MO, USA) and were used as received.

\subsection{Cells and Cytotoxicity Assay}

The cell lines that were used in this study were obtained from the American Type Culture Collection (ATCC) and were cultured, as described previously [25]. Primary PBMCs were obtained with informed consent (\# 031019/2013). All the cells were free of contamination, and the cell viability was determined by the TBE or $\mathrm{AB}$ assay, which were performed following the procedure that was described previously $[25,26]$. The cell morphology analysis was performed using cytospin and May-Grunwald-Giemsa staining as described previously [25]. To investigate caspase-3 activation, a caspase-3 colorimetric assay kit (Sigma-Aldrich Co.) was used.

\subsection{Flow Cytometric Assays}

Light scattering features were determined by flow cytometry. The internucleosomal DNA fragmentation and cell cycle distribution were determined according to Nicoletti et al. [27]. For apoptosis measurements, a FITC Annexin V Apoptosis Detection Kit I (BD Biosciences, San Jose, CA, USA) was used, and the analysis was performed, according to the manufacturer's instructions. A protection assay using the pan-caspase inhibitor Z-VAD(OMe)-FMK (Cayman Chemical, Ann Arbor, MI, USA) was also evaluated. The mitochondrial transmembrane potential was determined by the retention of the dye rhodamine 123 [28]. The levels of ROS were measured, as previously 
described [29], using $2^{\prime}, 7^{\prime}$-dichlorofluorescin diacetate (DCF-DA, Sigma-Aldrich Co.). At least $1 \times 10^{4}$ events were recorded per sample using a BD LSRFortessa cytometer along with BD FACSDiva Software (BD Biosciences) and Flowjo Software 10 (Flowjo LCC, Ashland, OR, USA). The cellular debris was omitted from the analysis.

\subsection{Statistical Analysis}

Data were analyzed and graphs were generated using GraphPad Prism software to evaluate significance. Differences among experimental groups were compared using analysis of variance (ANOVA), followed by the Student-Newman-Keuls test $(p<0.05)$.

Author Contributions: Conceived and designed the experiments: M.B.P.S., R.S.C., A.A.B. and D.P.B. Performed the synthesis and structural characterization of the novel complex: R.S.C. Evaluated the cellular effect of the complex: M.d.S.O. and Á.A.D.d.S. Analyzed the data: R.S.C., A.A.B., M.d.S.O., Á.A.D.d.S. and D.P.B. Contributed reagents/materials/analysis tools: M.B.P.S., A.A.B. and D.P.B. Wrote the paper: D.P.B.

Acknowledgments: The authors are grateful to the flow cytometry platform of FIOCRUZ-Bahia for collecting the flow cytometry data. This work received financial support and fellowships from the Brazilian agencies Conselho Nacional de Desenvolvimento Científico e Tecnológico (CNPq) and Fundação de Amparo à Pesquisa do Estado de São Paulo (FAPESP). In particular, R.S.C. would like to thank CNPq for the grants \#403588/2016-2 and \#308370/2017-1.

Conflicts of Interest: The authors have declared that there are no conflicts of interest.

\section{References}

1. Torre, L.A.; Bray, F.; Siegel, R.L.; Ferlay, J.; Lortet-Tieulent, J.; Jemal, A. Global cancer statistics, 2012. Cancer J. Clin. 2015, 65, 87-108. [CrossRef] [PubMed]

2. Lu, Y.; Shen, T.; Yang, H.; Gu, W. Ruthenium complexes induce HepG2 human hepatocellular carcinoma cell apoptosis and inhibit cell migration and invasion through regulation of the Nrf2 pathway. Int. J. Mol. Sci. 2016, 17, 775. [CrossRef] [PubMed]

3. Zeng, L.; Chen, Y.; Liu, J.; Huang, H.; Guan, R.; Ji, L.; Chao, H. Ruthenium(II) complexes with 2-phenylimidazo[4,5-f][1,10]phenanthroline derivatives that strongly combat cisplatin-resistant tumor cells. Sci. Rep. 2016, 6, 19449. [CrossRef] [PubMed]

4. Zheng, C.; Liu, Y.; Liu, Y.; Qin, X.; Zhou, Y.; Liu, J. Dinuclear ruthenium complexes display loop isomer selectivity to c-MYC DNA G-quadriplex and exhibit anti-tumour activity. J. Inorg. Biochem. 2016, 156, 122-132. [CrossRef] [PubMed]

5. Costa, C.O.D.; Araujo-Neto, J.H.; Baliza, I.R.S.; Dias, R.B.; Valverde, L.F.; Vidal, M.T.A.; Sales, C.B.; Rocha, C.A.G.; Moreira, D.R.M.; Soares, M.B.P.; et al. Novel piplartine-containing ruthenium complexes: Synthesis, cell growth inhibition, apoptosis induction and ROS production on HCT116 cells. Oncotarget 2017, 8, 104367-104392.

6. Siewert, B.; Langerman, M.; Hontani, Y.; Kennis, J.T.M.; van Rixel, V.H.S.; Limburg, B.; Siegler, M.A.; Talens Saez, V.; Kieltyka, R.E.; Bonnet, S. Turning on the red phosphorescence of a $[\mathrm{Ru}(\mathrm{tpy})(\mathrm{bpy})(\mathrm{Cl})] \mathrm{Cl}$ complex by amide substitution: Self-aggregation, toxicity, and cellular localization of an emissive ruthenium-based amphiphile. Chem. Commun. 2017, 53, 11126-11129. [CrossRef] [PubMed]

7. Oliveira, K.M.; Liany, L.D.; Corrêa, R.S.; Deflon, V.M.; Cominetti, M.R.; Batista, A.A. Selective Ru(II)/lawsone complexes inhibiting tumor cell growth by apoptosis. J. Inorg. Biochem. 2017, 176, 66-76. [CrossRef] [PubMed]

8. Chen, J.; Peng, F.; Zhang, Y.; Li, B.; She, J.; Jie, X.; Zou, Z.; Chen, M.; Chen, L. Synthesis, characterization, cellular uptake and apoptosis-inducing properties of two highly cytotoxic cyclometalated ruthenium(II) $\beta$-carboline complexes. Eur. J. Med. Chem. 2017, 140, 104-117. [CrossRef] [PubMed]

9. Carvalho, N.C.; Neves, S.P.; Dias, R.B.; Valverde, L.F.; Sales, C.B.; Rocha, C.A.G.; Soares, M.B.P.; Santos, E.R.; Oliveira, R.M.M.; Carlos, R.M.; et al. A novel ruthenium complex with xanthoxylin induces S-phase arrest and causes ERK1/2-mediated apoptosis in HepG2 cells through a p53-independent pathway. Cell Death Dis. 2018, 9, 79. [CrossRef] [PubMed]

10. Silva, V.R.; Corrêa, R.S.; Santos, L.S.; Soares, M.B.P.; Batista, A.A.; Bezerra, D.P. A ruthenium-based 5-fluorouracil complex with enhanced cytotoxicity and apoptosis induction action in HCT116 cells. Sci. Rep. 2018, 8, 288. [CrossRef] [PubMed] 
11. Lentz, F.; Drescher, A.; Lindauer, A.; Henke, M.; Hilger, R.A.; Hartinger, C.G.; Scheulen, M.E.; Dittrich, C.; Keppler, B.K.; Jaehde, U.; et al. Pharmacokinetics of a novel anticancer ruthenium complex (KP1019, FFC14A) in a phase I dose-escalation study. Anticancer Drugs 2009, 20, 97-103. [CrossRef] [PubMed]

12. Leijen, S.; Burgers, S.A.; Baas, P.; Pluim, D.; Tibben, M.; van Werkhoven, E.; Alessio, E.; Sava, G.; Beijnen, J.H.; Schellens, J.H. Phase I/II study with ruthenium compound NAMI-A and gemcitabine in patients with non-small cell lung cancer after first line therapy. Investig. New Drugs 2015, 33, 201-214. [CrossRef] [PubMed]

13. Correa, R.S.; Freire, V.; Barbosa, M.I.F.; Bezerra, D.P.; Bomfim, L.M.; Moreira, D.R.M.; Soares, M.B.P.; Ellena, J.; Batista, A.A. Ru(II)-thyminate complexes: New metallodrug candidates against tumor cells. New J. Chem. 2018, 42, 6794-6802. [CrossRef]

14. Yun, S.H.; Sim, E.H.; Han, S.H.; Kim, T.R.; Ju, M.H.; Han, J.Y.; Jeong, J.S.; Kim, S.H.; Silchenko, A.S.; Stonik, V.A.; et al. In vitro and in vivo anti-leukemic effects of cladoloside $\mathrm{C}_{2}$ are mediated by activation of Fas/ceramide synthase 6/p38 kinase/c-Jun $\mathrm{NH}_{2}$-terminal kinase/caspase-8. Oncotarget 2017, 9, 495-511. [PubMed]

15. Abu, E.l.; Maaty, M.A.; Almouhanna, F.; Wölfl, S. Expression of TXNIP in cancer cells and regulation by $1,25(\mathrm{OH})_{2} \mathrm{D}_{3}$ : Is it really the vitamin $\mathrm{D}_{3}$ upregulated protein? Int. J. Mol. Sci. 2018, 19, 796.

16. Calgarotto, A.K.; Maso, V.; Junior, G.C.F.; Nowill, A.E.; Filho, P.L.; Vassallo, J.; Saad, S.T.O. Antitumor activities of quercetin and green tea in xenografts of human leukemia HL60 cells. Sci. Rep. 2018, 8, 3459. [CrossRef] [PubMed]

17. Bezerra, D.P.; Militão, G.C.; Castro, F.O.; Pessoa, C.; Moraes, M.O.; Silveira, E.R.; Lima, M.A.; Elmiro, F.J.; Costa-Lotufo, L.V. Piplartine induces inhibition of leukemia cell proliferation triggering both apoptosis and necrosis pathways. Toxicol. In Vitro 2007, 21, 1-8. [CrossRef] [PubMed]

18. Magalhães, H.I.; Wilke, D.V.; Bezerra, D.P.; Cavalcanti, B.C.; Rotta, R.; de Lima, D.P.; Beatriz, A.; Moraes, M.O.; Diniz-Filho, J.; Pessoa, C. (4-Methoxyphenyl)(3,4,5-trimethoxyphenyl)methanone inhibits tubulin polymerization, induces $\mathrm{G}_{2} / \mathrm{M}$ arrest, and triggers apoptosis in human leukemia HL-60 cells. Toxicol. Appl. Pharmacol. 2013, 272, 117-126. [CrossRef] [PubMed]

19. Chen, L.; Li, G.; Peng, F.; Jie, X.; Dongye, G.; Cai, K.; Feng, R.; Li, B.; Zeng, Q.; Lun, K.; et al. The induction of autophagy against mitochondria-mediated apoptosis in lung cancer cells by a ruthenium (II) imidazole complex. Oncotarget 2016, 7, 80716-80734. [CrossRef] [PubMed]

20. Ouyang, L.; Shi, Z.; Zhao, S.; Wang, F.T.; Zhou, T.T.; Liu, B.; Bao, J.K. Programmed cell death pathways in cancer: A review of apoptosis, autophagy and programmed necrosis. Cell Prolif. 2012, 45, 487-498. [CrossRef] [PubMed]

21. Galluzzi, L.; Vitale, I.; Aaronson, S.A.; Abrams, J.M.; Adam, D.; Agostinis, P.; Alnemri, E.S.; Altucci, L.; Amelio, I.; Andrews, D.W.; et al. Molecular mechanisms of cell death: Recommendations of the Nomenclature Committee on Cell Death 2018. Cell Death Differ. 2018, 25, 486-541. [CrossRef] [PubMed]

22. Van Engeland, M.; Nieland, L.J.; Ramaekers, F.C.; Schutte, B.; Reutelingsperger, C.P. Annexin V-affinity assay: A review on an apoptosis detection system based on phosphatidylserine exposure. Cytometry 1998, 31, 1-9. [CrossRef]

23. Deng, Z.; Gao, P.; Yu, L.; Ma, B.; You, Y.; Chan, L.; Mei, C.; Chen, T. Ruthenium complexes with phenylterpyridine derivatives target cell membrane and trigger death receptors-mediated apoptosis in cancer cells. Biomaterials 2017, 129, 111-126. [CrossRef] [PubMed]

24. Wan, D.; Lai, S.H.; Zeng, C.C.; Zhang, C.; Tang, B.; Liu, Y.J. Ruthenium(II) polypyridyl complexes: Synthesis, characterization and anticancer activity studies on BEL-7402 cells. J. Inorg. Biochem. 2017, 173, 1-11. [CrossRef] [PubMed]

25. Santos, L.S.; Silva, V.R.; Menezes, L.R.A.; Soares, M.B.P.; Costa, E.V.; Bezerra, D.P. Xylopine induces oxidative stress and causes $\mathrm{G}_{2} / \mathrm{M}$ Phase arrest, triggering caspase-mediated apoptosis by $\mathrm{p} 53$-independent pathway in HCT116 cells. Oxid. Med. Cell. Longev. 2017, 2017, 7126872. [CrossRef] [PubMed]

26. Ahmed, S.A.; Gogal, R.M., Jr.; Walsh, J.E. A new rapid and simple non-radioactive assay to monitor and determine the proliferation of lymphocytes: An alternative to $\left[{ }^{3} \mathrm{H}\right]$ thymidine incorporation assay. J. Immunol. Methods 1994, 170, 211-224. [CrossRef]

27. Nicoletti, I.; Migliorati, G.; Pagliacci, M.C.; Grignani, F.; Riccardi, C. A rapid and simple method for measuring thymocyte apoptosis by propidium iodide staining and flow cytometry. J. Immunol. Methods 1991, 139, 271-279. [CrossRef] 
28. Sureda, F.X.; Escubedo, E.; Gabriel, C.; Comas, J.; Camarasa, J.; Camins, A. Mitochondrial membrane potential measurement in rat cerebellar neurons by flow cytometry. Cytometry 1997, 28, 74-80. [CrossRef]

29. LeBel, C.P.; Ischiropoulos, H.; Bondy, S.C. Evaluation of the probe $2^{\prime}, 7^{\prime}$-dichlorofluorescin as an indicator of reactive oxygen species formation and oxidative stress. Chem. Res. Toxicol. 1992, 5, 227-231. [CrossRef] [PubMed]

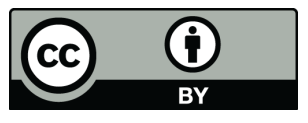

(C) 2018 by the authors. Licensee MDPI, Basel, Switzerland. This article is an open access article distributed under the terms and conditions of the Creative Commons Attribution (CC BY) license (http:/ / creativecommons.org/licenses/by/4.0/). 